УДК 340.12:347.61/.62(438-11)"1918/1939"

\title{
ПРОБЛЕМНІ ПИТАННЯ СІМЕЙНОГО ПРАВА НА СХІДНИХ ЗЕМЛЯХ ІІ РЕЧІ ПОСПОЛИТӦ̈
}

\author{
Ю. Дворас-Кулік \\ Люблінський католицький університет Яна Павла II, \\ Al. Ractawickie 14, 20-950 Lublin, \\ e-mail: judytadworas@kul.lublin.pl
}

Статтю присвячено проблемам сімейного права на східних землях II Речі Посполитої. Вони виникли передусім тому, що не було проведено кодифікації сімейного права, дію якого б поширили на усю територію держави і браку єдиної цивільної юрисдикції у сімейних справах не зважаючи на форму шлюбу, як це передбачав проект К. Лютостанського. Судова практика церковних судів спричинилася до появи шлюбів, які були недійсними і поширення такого явища, як легальна бігамія. Порушення норм права, що регулювали юрисдикцію церковних судів у справах про розірвання шлюбу чи визнання його недійсним, а також взаємне невизнання рішень церковних судів одного віросповідання церковними судами іншого віросповідання стали причиною появи територій названих «мекками розлучень». Сказане стосується Православної і Протестантської церков, що діяли на сході II Речі Посполитої. Беручи це до уваги, метою дослідження $є$ спроба комплексного аналізу чинників, що дестабілізували сімейне право на цих землях. Для досягнення мети передусім використано історико-правовий метод.

Ключові слова: легальна бігамія, російська окупація, міжвоєнний період, чоловік, церковний суд, укладення шлюбу, розлучення.

DOI: http://dx.doi.org/10.30970/vla.2020.70.088

Bcmyn. Після відновлення незалежності у 1918 році Польща, з метою забезпечення правопорядку, зберегла на своїй території дію законодавства державокупантів [9, с. 501: 5, с. 263-264], тож на сході II Речі Посполитої (віленське, новогрудське, поліське, волинське воєводства, та гроденський, вовковський, білостоцький, більський i сокальський повіти білостоцького воєводства) діяло канонічне сімейне право. Цивільне право, що теж застосовувалося на території східних земель II Речі Посполитої, передусім том X Зводу законів Російської імперії з подальшими змінами і доповненнями (далі 33) [Dz. U. 1927, Nr 31, poz. 258; 28, с. 28-36; 31, с. 169-170; 12, с. 509-513]. Успадковане по державахокупантах право трактували як іноземне, але дільничне польське право [34, c. 67-69; 4, с. 170]. Тривалий період анексії був причиною відсутності у Польщі власних нормативних актів, які б могли замінити австрійські, російські чи прусські кодекси. Давнє польське право, що діяло до поділів, було вже застарілим і цілком не пристосованим до тогочасних реалій суспільного життя, крім того, польська спільнота про нього вже забула, отож, і сприймала як дещо чужорідне. Поділ на дільниці (відповідно до зон окупації) і діючі в них окремі системи права сформували свідомість мешканців Речі Посполитої, що знайшло своє відображення у роботі над кодифікацією сімейного права міжвоєнної Польщі. Тут варто зауважити, що третє читання проєкту сімейного кодексу, автором якого був К. Лютостанський, відбулося 23-29 жовтня 1926 року, а сам проєкт був ухвалений Кодифікаційною комісією 4 жовтня 1927 року. Згодом його довго розглядали на

(C) Дворас-Кулік Ю., 2020 
Ю. Дворас-Кулік

ISSN 0136-8168. Вісник Львівського університету. Серія юридична. 2020. Випуск 70

рівні Підкомісії. Комітет організації праці ухвалив кінцеву редакцію проєкту 28 травня 1929 року, яку передали на розгляд Міністру юстиції 4 грудня 1929 року. Обгрунтування проєкту сімейного кодексу опублікували 9 грудня 1931 року, однак прийнятий він не був. Уряд, з огляду на суспільну думку, зокрема його консервативна частина [детальніше: 13 , с. 415-416 та 14, с. 756-759], відмовився від проєкту як основи діючого сімейного права Речі Посполитої. Комісія ж своєю чергою постановила, що іiі варіант є закінченим, остаточним і доопрацювання не потребує [детальніше: 15, с. 195-206]. У підсумку сімейне право міжвоєнного періоду не уніфікували, хоча такі спроби і робили $[29 ; 24$, с. 79-85; 19, с. 47-71].

Юрисдикція иерковних судів. Діяльність церковних судів регламентували внутрішні приписи, характерні для певного віросповідання чи релігійного об'єднання, одночасно право здійснювати судочинство у цивільних справах віруючих було компетенцією загальних судів. У розумінні цивільного права приписи окремих віровчень становили його невід'ємну частину, тобто вони були санкціоновані державою, що на практиці мало наслідком абсолютну відсутність нагляду за діяльністю у сфері права релігійних об'єднань та їхніх членів, і передусім це стосувалося юрисдикції у сфері стосунків, що виникали з факту укладення шлюбу, бо ж останню доручили виконувати церковним судам. Партикуляризм у праві уможливив існування відмінних причин розірвання шлюбу для кожного віросповідання.

На території східних земель II Речі Посполитої відповідно до 33 православне віросповідання було у привілейованому становищі, а тому на цій території плекали православ'я. Зокрема, шлюби православного з римо-католиком у присутності римо-католицького священника, вважалися недійсними, до моменту поки подружжя не отримає «благословення від православного священника» (ст. 72 33). Таке становище Православної церкви суперечило волі законодавця, що у 114 ст. березневої конституції визначив провідне становище римо-католицького віросповідання 3-поміж інших визнаних державою віросповідань. Православна церква у своїй діяльності керувалась ст. 115 березневої конституції, а тому не визнавала примату Католицької церкви [Конституція Речі Посполитої Польської, (Dz. U. 1921, Nr 44, poz. 267)]. Варто зазначити, що відповідно до висновку Верховного суду від 8 листопада 1926 року, [I C 260/25 (39, Nr 172/26)] норми права, що забезпечували переваги віросповідання православного над іншими віросповіданнями втратили свою чинність 3 моменту відродження польської державності [27, с. 15-32]. Отож, тимчасові приписи (достатньо поверхневі), що мали на меті врегулювати становище проросійської Православної церкви багато років були єдиною нормативною базою, що регулювали відносини Речі Посполитої і цієї Церкви, і це мало наслідком створення широких меж, у яких могла діяти церковна адміністрація. Вказане вище було причиною прагнень до відокремлення православної церкви у Польщі як автокефальної, без московського керівництва. Лише у 1938 році президент Речі Посполитої декретом окреслив відносини Держави і Польської Православної Автокефальної Церкви [Dz. U. 1938, Nr 88, poz. 597]. Вміщені у ньому положення фіксували стан речей, що існував до того (постанови Святого Собору Російського Церкви Православної у 1918 році та ухвали Святого Синоду Автокефальної Православної Церкви в Польщі від 1925-1928 років), за якими Польська Автокефальна Православна Церква зберегла єдність зі Загальною Східною Православною Церквою у справах догматичних і канонічних, залишаючись при цьому незалежною від будь-якої закордонної світської чи духовної влади [36, с. 599-605]. 
2Важливими правовими нормами, які впливали на правовий статус подружжя у Православній церкві були приписи ст. 73 і $74^{1}$ 33. У першій з названих статей зазначали, що якщо хтось із подружжя був православного віросповідання, то повноважним судом, до компетенції якого належало вирішення питання про існування шлюбу і його розірвання був церковний суд Православної церкви. У наступній з названих статей йшлося про мішані християнські подружжя (неправославні). Визначали, що повноважним судом для встановлення факту існування шлюбу, його дійсності був суд того віросповідання, священник якого надав благословення на укладення шлюбу, а в справах про розлучення повноважним судом вважали суд тієї церкви, до якої належав відповідач [16, с. 5; 25, с. 396-397; 38 , с. 587-588]. Прийняті таким шляхом рішення були обов'язковими для кожного 3 подружжя. На вказані приписи Католицька церква не зважала і розглядала усі справи, що стосувалися шлюбів та розлучень осіб, хрещених нею. Не впливала на ситуацію і пізніша зміна віросповідання, брали до уваги лише факт укладення шлюбу католицьким священником. Отже, католицькі церковні суди розглядали справи, що належали до підсудності церковних судів решти віросповідань [33, c. $596 ; 31$, с. $172 ; 35$, с. 1115$]$. Свою компетенцію вона також поширила на союзи між католиками і нехристиянами. У таких випадках щоразу приймали рішення про недійсність шлюбу, укладеного некатолицьким священником. Однак досить часто траплялися ситуації, у яких єпископські суди всупереч своїй винятковій судовій підвідомчості відмовлялися розглядати справи позивачів про розлучення, мотивуючи це внутрішніми правилами, оскільки вважали, що вирішення цієї справи не належить до їхньої підсудності. На практиці позивач, який з причин, що від нього не залежали, не міг вирішити свою справу у законний спосіб, подавав позов про розлучення до іншого церковного суду з метою отримати фактичне розлучення, яке з погляду цивільного права не було законним [8, с. 112-113; 37, с. 112].

Тут доречно буде звернути увагу на правила, якими керувався консистор Вільнюської Свангельської Реформованої Церкви у Речі Посполитій (Литовська спільнота), оскільки його діяльність стала причиною появи такого явища, як «легальна бігамія (двоєженство)» у міжвоєнній Польщі. Церковний суд Литовської спільноти розглядав справи про розірвання шлюбу, укладеного відповідно у визначеній законом формі, якщо бодай один із подружжя сповідував кальвінізм. Церковна консисторія Литовської спільноти у разі прийняття такого рішення керувалася нормами Порядку богослужінь, зокрема каноном 2 Синоду 1928 року, що регулював юрисдикцію церковного суду [35, с. 1153-1154]. 3 цього випливає, що вільнюський консистор розповсюджував свою цивільну юрисдикцію на осіб інших віросповідань, на яких поширювались інші релігійні приписи. У судовій практиці цього суду не брали до уваги, священник якого віросповідання благословив шлюб, а зважали лише на факт чи на момент розлучення бодай один із подружжя був прихожанином Свангельської Реформованої Церкви. Найпоширенішими спорами про компетенцію, були спори про розлучення подружжя римокатоликів, що уклали шлюб у Римо-католицькій церкві, а згодом один із подружжя змінив віросповідання на євангельське реформоване і подав до вільнюського консистора позов про розлучення з дружиною-католичкою. Вільнюський консистор трактував це так: західна губернія російської імперії - це територія Вільнюської Євангельської Реформованої Церкви, а тому ії широка юрисдикція грунтувалася на положеннях березневої конституції 1921 року (що гарантувала рівноправ'я віросповідань) та конкордаті підписаному з Апостольською Столицею у 1925 році, за яким канонічне право визнавали системою норм права, які були підставою 
Ю. Дворас-Кулік

ISSN 0136-8168. Вісник Львівського університету. Серія юридична. 2020. Випуск 70

визначення юрисдикції і здійснення церковної влади, що, на думку консистора, дозволяло окремим релігійним організаціям, визнаним державою у своїй внутрішній діяльності застосовувати норми канонічного права без жодних обмежень. Наочною ілюстрацією буде випадок вільнюського консистора К. Остахевіча, якого за прийняття до спільноти польських громадян, що змінювали віросповідання винятково 3 метою отримання розлучення (тобто тих, які не відчували жодної потреби у духовних практиках новообраної релігії), було відлучено від Церкви. Разом із консистором від Церкви відійшли і його прихильники, прихожани Віленської церкви. Згодом, пастор долучився до Варшавської спільноти й у 1933 році створив свій осередок у Вільнюсі.

Все ж таки церковний суд Свангельської реформованої церкви у випадку, коли один із подружжя був прихожанином Римо-католицької церкви, вважав необхідним повідомляти відповідний єпископський суд про розгляд справи про розлучення подружжя, укладеного за католицьким обрядом. Отримавши таку інформацію Римо-католицька церква делегувала свого представника (депутата) для партисипації у процесі розлучення, який у рішенні про розлучення, як правило, висловлював votum separatum (окрему думку) з мотивів неможливості розлучення для католика.

Без сумніву, церковні суди не визнавали рішень церковних судів інших віросповідань, що породжувало колізії судових рішень. Ці суди конкурували між собою, «виривали» справи, що належали не до їхньої підсудності, а як наслідок їхнє рішення не створювало жодних правових наслідків 3 погляду цивільного права. Церковні суди приймали рішення у тій самій справі, проголошуючи різні рішення і цим порушували принцип остаточності рішення (res judicata) [18, c. 257-260; 11, с. 229-247]. Це призводило до того, що виникали ситуації, коли шлюб, формально розірваний чи визнаний недійсним, продовжував існувати, адже Верховний суд своїм рішенням від 8 листопада 1926 року створив прецедент. Позиція Суду була такою: не може ітися про застосування принципу res judicata для рішень, що не існували 3 погляду цивільного права, а саме такими були рішення, видані з порушенням законів, що встановлювали компетенцію судів [I C 260/25]. Доручення церковним судам виносити рішення у цивільних справах без можливості контролювати правильність виданих ними рішень на практиці призводило до виникнення фіктивних юридичних становищ, що не мали тих юридичних наслідків, яких бажали сторони процесу. На жаль, скасовувати помилкові рішення церковних судів не належало до компетенції державних судів, бо перші не належали до судів загальної юрисдикції, а були незалежними судами, підпорядкованими окремим Церквам [8, с. 116]. Юридичні колізії, що виникали у разі розірвання змішаних шлюбів, вирішив Верховний суд і у висновку Загального зібрання Вищого суду від 24 листопада 1928 року [Nr O.Z. 1/23 O.S.P. 133/III ] вказав, що у випадку, коли позивачем був католик, а відповідачем особа, що сповідувала євангелізм, повноважним судом для прийняття рішення про розлучення був євангельський суд, який допускав розлучення. У випадку, коли позивачем у справі виступав той 3 подружжя, що змінив віросповідання на євангельське, повноважним судом був Єпископський суд. У такому випадку прийняття рішення про розлучення було неможливим, бо канонічне право не передбачало можливості прийняття рішення про розірвання шлюбу. Верховний суд чітко зазначив, що рішення, прийняті з порушенням підсудності «не мають жодних юридичних наслідків. Оскільки розірвання шлюбу є одночасно релігійним актом, як і юридичним фактом у розумінні цивільного права, тому рішення про розлучення, прийняте 3 порушенням вимог підсудності вважатиметься нікчемним». 
Окрім того, Верховний суд зазначив, що церковний суд не може виходити за межі, чітко окреслені цивільним правом, адже в протилежному випадку «держава не буде визнавати рішення церковного суду». Також Верховний суд зауважив, що оцінку державними судами підсудності справ церковним судам не варто вважати втручанням у цивільну юрисдикцію церковних судів, адже державні суди не проводили оцінку обгрунтованості та вмотивованості рішення прийнятого церковним судом, а лише перевіряли чи не були порушені норми цивільного законодавства, що забезпечували законність рішення церковного суду» [20, с. 751-754].

Шлюборозлучна міграція населення Польщі. Доцільно зазначити, в міжвоєнний період у Польщі не було правових норм, що могли б подолати правові колізії в законах та підзаконних нормативних актах, що досить незграбно намагалися замінити регулювання приватних відносин нормами права, яке було чинним у державокупантів. Як мовилось у висновку Верховного суду: «Неузгодженість матеріального і процесуального законодавства, що регулювало сімейні відносини, яка спостерігалась у різних дільницях держави, мала наслідком, що рішення обов'язкове до виконання відповідно до законодавства однієї дільниці було безумовно чинним і на території іншої дільниці. Тож поширення обов'язковості рішення, прийнятого на підставі законодавства, чинного на території однієї з дільниць, на інші дільниці мусило спричинити хаос, про який свідчить факт, що принцип нерозривності шлюбу, укладеного між католиками і взагалі неможливості розпочати шлюборозлучний процес між таким подружжям, який містився в австрійському цивільному кодексі, фактично був ліквідований рішеннями церковних судів, виданих на підставі законів, чинних на території дільниці, що свого часу була під російською окупацією» [C II R 351/ 33, 39, Nr 1934/108]. Існуючу прогалину в праві усувала тогочасна судова практика, насамперед практика Верховного суду. Лише на підставі закону від 2 серпня 1926 року «Про порядок законодавчого регулювання цивільних відносин у Польщі (Право приватне міждільничне)» [Dz.U. 1926, Nr 101, poz. 580] було припинено дію права колишніх держав-окупантів, що діяло до того часу. Згідно з рішенням Верховного суду від 23 жовтня 1936 року [III C 888/36, 39, 1937, poz. 174] «Право приватне міждільничне, як право що цілком самостійно регулює певні правовідносини, не може за аналогією застосовуватися щодо правочинів, які були вчинені до набуття ним чинності, до цих правочинів слід застосовувати норми приватного права, яке містилось у цивільних кодексах, що обули чинними у той час» [8, с. 110-111; 21, с. 278-288].

Основною причиною невизначеного правового статусу окремих громадян у сфері сімейного права було поширення міграції населення $з$ одних дільниць Речі Посполитої до інших, оскільки остання впливала на визначення повноважного суду у конкретній сімейній справі. Порядок визначення повноважного суду був врегульований розпорядженням Президента Речі Посполитої від 6 лютого 1928 року «Законодавство про загальний судоустрій» [Dz.U. 1928, Nr 12, poz. 9]. Відбувалося це так, оскільки відповідно до ст. 2 згаданого закону від 2 серпня 1926 року чоловік отримував нові права у сфері сімейного права через рік після зміни місця проживання, а відповідно до п. 1 і 2 ст. 3 цього закону місцем проживання дружини визнавали місце проживання ії чоловіка, тож на неї поширювалася дія тих норм права, що були обов'язковими для нього. Дружина мала право на роздільне проживання $з$ чоловіком у місці, визначеному судом лише у випадку прийняття щодо подружжя рішення про сепарацію (роздільне проживання) чи у випадку, коли місцезнаходження іiі чоловіка було невідомим або його було визнано недієздатним (у такому разі над ним встановлювали опіку і він втрачав свою доміцилію) 
Ю. Дворас-Кулік

ISSN 0136-8168. Вісник Львівського університету. Серія юридична. 2020. Випуск 70

[I. C. 777/28, 39, 1929, poz. 85]. Чоловік, як привілейована сторона, мав право самостійно змінити проживання, обравши дільницю, де діяли вигідніші для нього закони, що поширювались і на дружину та у розумінні ст. 17 і п. 1 і 2 закону від 2 серпня 1926 року були спільним для подружжя правом, на підставі якого варто було приймати рішення про розлучення. Треба наголосити, що для подання цивільного позову стосовно шлюбу, в якому бодай один із подружжя мав польське громадянство, повноважним вважали суд за місцем їхнього останнього спільного проживання, якщо бодай одне 3 подружжя продовжувало там проживати [2, с. 614]. Інакше повноважним вважали суд за місцем проживання відповідача і насамкінець позивача (ст. 43 Цивільного процесуального кодексу) [Dz. U. $1930 \mathrm{Nr} 83$ poz. 651]. Норми міждільничного права поширювалися і на шлюби, укладені державою, в присутності чиновника, що реєстрував акти цивільного стану, укладені після набрання чинності вказаного закону, та на шлюби польських громадян, на яких поширювалася дія російського права, які були зареєстровані державою до набрання чинності закону про міждільничне право, якщо шлюбні стосунки тривали далі, а сам шлюб не був у встановленому порядку розірваний чи визнаний недійсним [38, с. 596].

Доречно вказати, що з 25 червня 1929 року Польща приєдналася до Гаазької міжнародної конвенції, що регулювала колізії законів та визначала юрисдикцію стосовно розірвання шлюбів і сепарації [Dz.U. 1929, Nr. 80, poz. 594; Dz.U. 1929, Nr. 80, poz. 595; Dz. U. 1929, Nr 80, poz. 597]. У польському законодавстві вказані норми міжнародного права мали таке ж значення, як і національне законодавство. Було передбачено, що вказана конвенція набере чинності через три роки. Саме вона стала взірцем для польського законодавця при редагуванні польського права у сфері сімейного права. У разі співставлення тексту гаазької конвенції та польського закону «Про право приватне міждільничне» очевидно, що законодавець імплементував норми міжнародного права шляхом спеціальної трансформації, перетворення норм міжнародного права на норми національного права через їхнє залучення у відповідні акти. Тож порівнювані тексти відрізняються лише дрібними деталями.

Верховний суд постановив, що бажання розлучитися в особи виникає 3 моменту подання позову про розлучення і триває протягом розгляду справи в суді. Тому зміна місця проживання з подальшим переходом під дію іншого дільничного права до винесення рішення по суті справи змінює правові підстави, якими керується суд при прийнятті рішення. Отож, Верховний суд постановив, що законодавча вимога про річне проживання на території дільниці вважалася виконаною, якщо рік минав на момент оголошення рішення у справі, а не на момент подання позову [C. III. 836/35, 39, Nr 1936/287; 8, c. 111-112; 32, с. 171].

Тут варто звернути увагу на питання проживання дружини. Відповідно до діючого права на неї було покладено обов'язок слідувати за чоловіком і мешкати разом із ним у обраному ним місці, тому права, яких він набував, поширювались i на дружину, навіть у випадку, коли вона фактично перебувала в іншому місці. Тут наявна прогалина у законодавстві, адже законодавець відповідно до норм приватного міждільничного права при винесенні рішення про розлучення вимагав встановлення останнього місця спільного проживання чоловіка і дружини. Дружина могла не знати про набуття чоловіком нових прав і навіть про сам факт розлучення, бо він міг іiі покинути давніше і виїхати без неї. Укладення нового шлюбу таким чоловіком з погляду закону було бігамією (двоєженством). Судова практика теж була причетною до порушення строку, визначеного законом про міждільничне право, адже вона надала можливість позивачу ще до спливу річного терміну проживання на території дільниці і до набуття ним права на отримання розлучення 
подати позов за місцем проживання, а отже вимагати права, якого він ще не набув. Набуття чинності закону про право міждільничне створило ситуацію, в якій цивільні шлюби зареєстровані державою 3 дотриманням вимог латинського типу шлюбу, у випадку зміни місця проживання та перебування на території дільниці, де діяло російське право, могли бути розірвані на підставі приписів канонічного права [I.N. 7/29, OSP 1931, poz. 300].

Проблема юрисдикиії цุивільних илюбів. Внутрішні церковні правила не застосовували до цивільних шлюбів зареєстрованих державою, якщо вони не були доповнені релігійними обрядами, і в такій ситуації подружжя було позбавлене права звертатися до суду. Тільки державні суди могли бути повноважними при розгляді справ, що виникали у спорах про укладення, розірвання чи визнання шлюбу недійсним, якщо він був зареєстрований державою, бо такі шлюби вважали правочинами [1, с. 114-115]. Саме тому тільки державні суди мали чинити правосуддя у питаннях визнання цивільного шлюбу недійсним чи розлучення цивільного подружжя. Прогалину у законодавстві частково долали висновки Верховного суду, згідно з якими, органи державної влади визнавали компетенцію церковних судів у спорах, що виникали 3 союзів, де шлюб мав характер релігійного таїнства. Цивільний шлюб, що не був доповнений релігійним обрядом, не вважався актом віри, а отже і рішення церковного суду у справі, що належала до компетенції державного суду, не мало юридичної сили.

Тут доцільно зазначити, рішення церковного суду неуповноваженого до розгляду в конкретній справі, хоча і було позбавлене юридичної сили, вважали скасованим лише у момент прийняття відповідного рішення повноважним церковним судом. У такому випадку особа, що в очах громадськості була звільнена від виконання шлюбних обітниць 3 погляду цивільного права і надалі перебувала у законному шлюбі. Повторне одруження такої особи трактували як двоєженство. Адже відповідно до висновку Верховного суду: «...поки шлюб зареєстрований органом реєстрації цивільного стану у 1925 р., не був визнаний недійсним чи розірваним повноважним судом, цей союз з точки зору цивільного права $є$ чинним і породжує усі можливі юридичні наслідки» [I. С. 701/31, 39, Nr 1932/10; 8, с. 109$130 ; 38$, с. $590 ; 37$, с. $111-112 ; 32$, с. $173 ; 35$, с. $1150-1158,26$, с. $15-28]$.

Реєстрація актів цивільного стану. Пастирі, що відповідали за реєстрацію актів цивільного стану, як і при здійсненні судочинства в справах про шлюб, керувалися внутрішнім церковним правом, що на практиці призводило до порушення діловодства при веденні реєстрів, завищення плати за надання витягу 3 таких реєстрів чи фальшування записів, що в них містилися. Численні помилки та інші недоліки допущені при складанні актів цивільного стану [23, с. 405-406] виникали тому, що ведення цих справ всупереч чинному законодавству доручали особам, які не мали належної кваліфікації. Зазвичай метричні i парафіяльні книги за дорученням керівництва парафії вели органісти, вони ж і зберігали вказані книги у себе вдома, що створювало додаткові сприятливі умови для допущення помилок чи свідомої підробки метричних записів. Беззаконню сприяла простота отримання розлучення від консистора за умови переходу в православ'я. Крім того, судовий контроль, як і адміністративний нагляд органів влади, за діяльністю парафії, були неефективними, адже жодна державна інституція не мала права притягнути церковних урядників, що реєстрували акти цивільного стану, до дисциплінарної відповідальності за допущені порушення. Тож органи влади не мали права застосовувати адміністративно-правові санкції до священнослужителів, відповідальних за ведення реєстрів цивільного стану, а служителі греко-католицьких 
Ю. Дворас-Кулік

ISSN 0136-8168. Вісник Львівського університету. Серія юридична. 2020. Випуск 70

дієцезій відмовлялися визнавати реєстри актів цивільного стану офіційними документами і саме це викликало найгостріші суперечки. Зважаючи на викладене вище, державний нагляд над органами реєстрації актів цивільного стану був фіктивним [6, с. $72-74 ; 8$, с. $115 ; 22$, с. $239-240 ; 25$, с. 502-503].

Без сумніву, за умови відсутності згадки про шлюб в актах реєстрації цивільного стану, можливо було укласти новий шлюб без розірвання попереднього, адже перший шлюб з погляду закону не існував. За відсутності актового запису чи відсутності правильного запису вважали, що правовий статус особи залишався незмінним. Тобто покинута дружина, не мала можливості відстояти у суді свої права, що виникали на підставі шлюбу, бо ж не було можливості довести, що він існував. Ще одним наслідком відсутності реєстрації шлюбу було невизнання дітей, народжених у такому союзі, законними, що своєю чергою призводило до відмови держави від охорони прав таких дітей. Понад те, держава не визнавала існування незареєстрованих дітей. Наприклад, Верховний суд відмовив жінці єврейського віросповідання, шлюбний союз якої відбувся в релігійній формі, у стягненні аліментів на утримання спільної дитини і зазначив, що «надання шлюбам, укладеним у формі релігійного обряду, рівних прав 3 шлюбами, що укладені відповідно до закону, буде порушенням права» [C III 16/35, 39, 1937, poz. 211; 6, с. 72; 22 , с. 240]. Міждільнична міграція сприяла поширенню цього явища, адже народження дитини у цивільному шлюбі не могло бути записане у парафіяльних реєстрах, що мали офіційний статус у Східній Польщі.

Доцільно зазначити, що укладення нового шлюбу одним із подружжя, яке було укладене у формі релігійного обряду та не було зареєстроване у книгах цивільного стану, а саме такі шлюби найчастіше укладали євреї, з погляду закону не вважали бігамією. Більше того, належна реєстрація другого шлюбу за одночасної відсутності доказів існування першого шлюбу, породжувало правові наслідки тільки для другого 3 подружжя і права, які виникали з факту укладення шлюбу, отримувала лише друга дружина та їі діти.

Наслідки розлучення чи визнання шлюбу недійсним. Відповідно до вимог ст. 40 33, особи, які не жили разом у зв'язку з укладенням одним із подружжя нового шлюбу всупереч тому, що попередній шлюб розірваний не був, мали право відновити попередню сім'ю, якщо покинута дружина чи чоловік не заперечували. Укладати новий шлюб, інакше як у випадку смерті когось із подружжя, закон забороняв.

При цьому, потерпіла дружина, щодо якої було прийнято неправильне рішення церковного суду, мала право домагатися реалізації усіх прав і отримання усіх вигод, що виникали з факту укладення шлюбу [І.С. 260/25]. С. Тильбор звертав увагу, що «у випадку спору держава має справу з двома формально дійсними шлюбами, що були розмежовані рішенням церковного суду про розлучення. Постає питання, чому держава має вважати другий шлюб непорушним, попри те, що і перший шлюб з формального погляду є нерозірваним. Застереження, що між першим і другим шлюбом було прийнято рішення про розлучення, не має значення, якщо відповідне рішення прийняв церковний суд. Рішення церковного суду може бути доказом розлучення тільки у випадку, якщо воно було прийняте відповідно до вимог цивільного закону. Якщо ж рішення таким вимогам не відповідає, воно є нікчемним і доцільно вважати, що розлучення ніколи не було» [38, с. 590]. Як правило дружина від першого шлюбу подавала до державного суду позов до дружини від другого шлюбу про визнання другого шлюбу недійсним та відновлення їі прав як дружини [N C. I. 1443/37; I. C. 1041/27; 8, с. 116-121]. 
Іншу позицію демонстрував Вищий адміністративний трибунал, який висловив думку, що з'ясування факту дійсності шлюбу, який було укладено після розлучення чи визнання недійсним попереднього шлюбу не належить до компетенції органів влади. Контроль за рішеннями церковних судів про припинення шлюбу Вищий адміністративний трибунал трактував як порушення закону. Опираючись на таку позицію Вищого адміністративного трибуналу органи влади визнавали майнові права по померлому чоловіку лише за другою дружиною, відмовляючи в аналогічних правах першій дружині, рішення про розлучення з якою було неправосудним. Коли ж дружина від першого шлюбу відповідно до ст. 3. Цивільного процесуального кодексу домоглася відновлення своїх прав як дружини у державному суді, органи влади, приймаючи рішення про юридичні наслідки шлюбу, мусили врахувати цей факт і взяти до уваги претензії обидвох дружин та визнати за ними рівні права на отримання утримання по померлому чоловікові [I. C. $1648 / 32 ; 8$, c. 118-119].

Дії чоловіка-двоєженця - це не тільки описані вище цивільні наслідки, а й грубе порушення закону, вчинення злочину двоєженства. Кримінальний закон під загрозою покарання змушував його дотримуватися приписів цивільного права, тому з погляду кримінального права внутрішні правила окремих церков значення не мали, якщо видані консистором рішення суперечили цивільному закону. Порушення останнього в цьому випадку було кримінально караним діянням і проти особи порушували кримінальну справу за двоєженство [7, с. 17-39].

Висновки. 3 погляду цивільного права шлюб як союз чоловіка і дружини був угодою, що характеризувалася як угода важливого суспільного значення, а тому санкції, що регулювали порядок укладення і припинення шлюбу мали на меті охорону приватних інтересів особи й одночасно охорону публічних інтересів. Невігластво чоловіків щодо наслідків судового рішення прийнятого 3 порушенням закону у випадку повторного одруження ускладнювало їхнє становище, і в очах закону робило їх двоєженцями. Чоловіка, який не знав юридичних тонкощів, вважали таким, що прийняв рішення церковного суду хоча останнє і не було юридично значимим. Його розлучення було вдаваним і 3 погляду цивільного права шлюб продовжував існувати, а новий шлюб держава трактувала як бігамію. Укладені нові шлюби в таких випадках мали юридичні наслідки, адже державні суди не могли ані прямо, ані опосередковано прийняти рішення «про недійсність такого шлюбу, або ж визнати ці шлюби такими, що не створюють жодних прав і обов'язків для подружжя» [35, с. 11-57]. Органи влади також не могли притягнути до відповідальності кліриків, що приймали рішення у справах шлюбу чи вели книги реєстрації актів цивільного стану, адже вони не були державними службовцями, яких можна було притягнути до відповідальності за невиконання службових обов'язків.

\section{Список використаних джерел}

1. Allerhand M. Jurysdykcja władz wyznaniowych w sprawach małżeńskich / M. Allerhand // Czasopismo Sędziowskie. 1937. R. XI, nr 3. S. 113-123.

2. Allerhand M. Miejscowa właściwość sądu dla spraw ze stosunku małżeństwa / M. Allerhand // Polski Proces Cywilny. 1936. R. IV, nr 20-21. S. 609-617.

3. Allerhand M. Międzydzielnicowe prawo procesowe w państwie polskiem z uwzględnieniem stosunków przejściowych / M. Allerhand. Warszawa, 1920.

4. Allerhand M. Stosunek prawa państwowego do prawa religijnego / M. Allerhand // Głos Prawa. 1927. R. IV, nr 5-6. S. 170-175.

5. Dyjakowska M. Prawo cywilne - część ogólna / M. Dyjakowska // Synteza prawa polskiego 1918-1939 / red. T. Guz, J. Głuchowski, M. R. Pałubska. Warszawa, 2013. S. 263-297. 
6. Dworas-Kulik J. Civil Registration in the Interwar Period in Poland / J. Dworas-Kulik // Scientific Challenges. Economic and Legals Challenges. 2017. T. 1. S. 69-77.

7. Dworas-Kulik J. Prawnokarne aspekty bigamii w Polsce w okresie dwudziestolecia międzywojennego / J. Dworas-Kulik // Roczniki Nauk Prawnych”. 2017. T. XXVII, nr 2. S. 17-39.

8. Dworas-Kulik J. Przyczyny i skutki legalnej bigamii w Polsce w okresie międzywojennym / J. Dworas-Kulik // Pogranicza w historii prawa i myśli polityczno - prawnej / red. D. Szpoper, P. Dąbrowski. Gdańsk ; Olsztyn, 2017. S. 109-130.

9. Dziadzio A. Austriacki kodeks cywilny ABGB na ziemiach polskich w XX wieku / A. Dziadzio // Ustrój i prawo w przeszłości dalszej i bliższej / red. J. Malca i W. Uruszczaka. Kraków, 2001. S. 501-514.

10. Fastyn A. Problem powstania i charakteru prawa małżeńskiego z 1836 roku / A. Fastyn // Czasopismo Prawno-Historyczne. 2012. T. LXIV, nr 2. S. 193-209.

11. Fastyn A. Zawarcie małżeństwa mieszanego wyznaniowo według prawa małżeńskiego $\mathrm{z}$ 1836 roku / A. Fastyn // Czasopismo Prawno - Historyczne. 2013. R. LXV, z. 1. S. 229-247.

12. Fiedorczyk P. Prawo rodzinne ziem wschodnich II Rzeczypospolitej [w:] Wielokulturowość polskiego pogranicza. Ludzie - idee - prawo / P. Fiedorczyk ; red. A. Lityński, P. Fiedorczyk. Białystok, 2003. S. 509-513.

13. Fiedorczyk $P$. Unifikacja prawa rodzinnego na tle stosunków pomiędzy państwem a kościołem katolickim w Polsce (1944-1964) / P. Fiedorczyk // Cuius regio, eius religio. Zjazd Historyków Państwa i Prawa. Lublin, 20-23 IX 2006 r. / red. G. Górski, L. Ćwikła, M. Lipska. Lublin, 2006. S. 415-431.

14. Godlewski J. Problem laicyzacji osobowego prawa małżeńskiego w Polsce międzywojennej / J. Godlewski // Państwo i Prawo. 1967, z. 11. S. 754-756.

15. Górnicki L. Prawo cywilne w pracach Komisji Kodyfikacyjnej Rzeczypospolitej Polskiej w latach 1919-1939 / L. Górnicki. Wrocław, 2000.

16. Gwiazdomorski J. Skuteczność orzeczeń sądów duchownych b. Król. Kongr. w sprawach małżeńskich wobec prawa państwowego / J. Gwiazdomorski // Przegląd Prawa i Administracji. 1932. R. LVII, nr 1. S. 4-23.

17. Gwiazdomorski J. Trudności kodyfikacji osobowego prawa małżeńskiego w Polsce / J. Gwiazdomorski // Osobne odbicie z "Czasopisma Prawniczego". Kraków, 1935. S. 174-223.

18. Hahn Z. Powaga rzeczy osądzonej / Z. Hahn // Polski Proces Cywilny. 1935. R. III, nr 9. S. 257-260.

19. Jaglarz J. Problem kodyfikacji prawa małżeńskiego w Polsce / J. Jaglarz. Poznań, 1934.

20. J. G. Z praktyki jednego z konsystorzy ewangelickich / J. G. // Gazeta Sądowa Warszawska. 1929. R. LVII, nr 8. S. 119-120.

21. Jastrzębski R. Prawo Prywatne międzydzielnicowe. Zarys problematyki / R. Jastrzębski // Krakowskie Studia z Historii Państwa i Prawa. 2015. R. VIII, nr 3. S. 277-298.

22. Krasowski K. Prawo o aktach stanu cywilnego w II Rzeczypospolitej / K. Krasowski // Kwartalnik Prawa Prywatnego. 1995. R. IV, z. 2. S. 227-252.

23. Litwin J. Rejestracja stanu cywilnego / J. Litwin, A. Rżewski. Warszawa, 1931.

24. Mika K. Małżeńskie prawo osobowe w projekcie Zygmunta Lisowskiego z 1934 r. / K. Mika // Prawo blisko człowieka. Z dziejów prawa rodzinnego i spadkowego / red. M. Mikuła. Kraków 2007. S. 79-85.

25. Osuchowski J. Prawo wyznaniowe Rzeczypospolitej Polskiej 1918-1939 / J. Osuchowski. Warszawa, 1967.

26. Paciorkowski Sz. Problem tzw. legalnej bigamii w II RP w świetle spraw małżeńskich toczonych przed Sądem Okręgowym w Poznaniu / Sz. Paciorkowski // Rezpozytorium Uniwersytetu im. Adama Mickiewicza. 2013. Z. 2. S. 15-28.

27. Papierzyńska-Turek M. Kosciół prawosławny w Polsce w latach 1918-1927 - sytuacja prawna i konflikty wewnętrzne / M. Papierzyńska-Turek // Dzieje Najnowsze. 1976. R. VIII. S. 15-32. 
28. Piegzik A. Przeszkody małżeńskie w ustawodawstwie dzielnicowym II RP / A. Piegzik // Folia Iuridica Wratislaviensis. 2016. Vol. 5 (1). S. 28-36.

29. Prawo małżeńskie (projekt ustawy) / oprac. Z. Lisowski. Poznań, 1934.

30. Prądzyński E. Zagadnienie ważności małżeństw cywilnych / E. Prądzyński // Palestra. 1937. R. XIV, nr 5. S. 438-444.

31. Radwański Z. Historia Państwa i Prawa Polski 1918-1939 / Z. Radwański. / red. F. Ryszki. Warszawa, 1968. Cz. II.

32. Radwański Z. Prawo cywilne i proces cywilny / Z. Radwański // Historia państwa i prawa Polski 1918-1939 / red. F. Ryszka. Warszawa 1968. Cz. II. S. 169-177.

33. Szymański T. Skutki prawne wyroków sądów duchownych / T. Szymański // Głos Sądownictwa. 1932. R. IV, nr 10. S. 595-603.

34. Świątkowski H. Jeszcze o działalności sądów konsystorskich / H. Świątkowski // Gazeta Sądowa Warszawska. 1934. R. LXII, nr 5. S. 67-69.

35. Świątkowski H. Problem legalnej bigamii w Polsce przedwrześniowej / H. Świątkowski // Nowe Prawo. 1959. Vol. 15, z. 10. S. 1150-1158.

36. Światkowski H. Stan Prawny Polskiego Autokefalicznego Kościoła Prawosławnego (w zarysie) / H. Świątkowski // Głos Sądownictwa. 1939. R. XI, nr 7-8. S. 599-605.

37. Świątkowski H. Z praktyki sądów konsystorskich / H. Świątkowski // Głos Sądownictwa. 1938. R. X, nr 2. S. 107-114.

38. Tylbor S. Dzisiejsze prawo małżeńskie w b. Królestwie Kongresowym / S. Tylbor // Głos Sądownictwa. 1939. R. XI, nr 7-8. S. 581-599.

39. Zbiór Orzeczeń Sadu Najwyższego. [Żródło elektroniczne]. Dostęp : http://www.sn.pl/orzecznictwo/SitePages/Baza_orzeczen.aspx [dostęp 1.03.2020]

\section{References}

1. Allerhand, M. (1937). Jurysdykcja władz wyznaniowych w sprawach małżeńskich. Czasopismo Sędziowskie, R. XI, nr 3, 113-123.

2. Allerhand, M. (1936). Miejscowa właściwość sądu dla spraw ze stosunku małżeństwa. Polski Proces Cywilny, R. IV, $n$ r 20-21, 609-617.

3. Allerhandm, M., Międzydzielnicowe prawo procesowe $\mathrm{W}$ państwie polskiem $\mathrm{z}$ uwzględnieniem stosunków przejściowych. Warszawa, 1920.

4. Allerhand, M. (1927). Stosunek prawa państwowego do prawa religijnego. Głos Prawa, R. IV, $n$ r 5-6, 170-175.

5. Dyjakowska, M. (2013). Prawo cywilne - część ogólna, [w:] Synteza prawa polskiego 1918 1939, red. T. Guz, J. Głuchowski, M. R. Pałubska. Warszawa, 263-297.

6. Dworas-Kulik, J. (2017). Civil Registration in the Interwar Period in Poland. Scientific Challenges. Economic and Legals Challenges", t. 1, 69-77.

7. Dworas-Kulik, J. (2017). Prawnokarne aspekty bigamii w Polsce w okresie dwudziestolecia międzywojennego. Roczniki Nauk Prawnych, t. XXVII, nr 2, 17-39.

8. Dworas-Kulik, J. (2017). Przyczyny i skutki legalnej bigamii w Polsce w okresie międzywojennym. [w:] Pogranicza w historii prawa i myśli polityczno - prawnej / red. D. Szpoper, P. Dąbrowski, Gdańsk. Olsztyn, 109-130.

9. Dziadzio, A. (2001). Austriacki kodeks cywilny ABGB na ziemiach polskich w XX wieku [w:] Ustrój i prawo w przeszłości dalszej i bliższej / red. J. Malca i W. Uruszczaka. Kraków, 501-514.

10. Fastyn, A. (2012). Problem powstania i charakteru prawa małżeńskiego z 1836 roku. Czasopismo Prawno-Historyczne, T. LXIV, nr 2, 193-209.

11. Fastyn, A. (2013). Zawarcie małżeństwa mieszanego wyznaniowo według prawa małżeńskiego z 1836 roku. Czasopismo Prawno-Historyczne, R. LXV, z. 1, 229-247. 
12. Fiedorczyk, P. (2003). Prawo rodzinne ziem wschodnich II Rzeczypospolitej. [w:] Wielokulturowość polskiego pogranicza. Ludzie - idee - prawo / red. A. Lityński, P. Fiedorczyk. Białystok, 509-513.

13. Fiedorczyk, P. (2006). Unifikacja prawa rodzinnego na tle stosunków pomiędzy państwem a kościołem katolickim w Polsce (1944-1964). [w:] Cuius regio, eius religio. Zjazd Historyków Państwa i Prawa. Lublin, 20-23 IX 2006 r. / red. G. Górski, L. Ćwikła, M. Lipska. - Lublin, 415-431.

14. Godlewski, J. (1967). Problem laicyzacji osobowego prawa małżeńskiego w Polsce międzywojennej. Państwo i Prawo, z. 11, 754-756.

15. Górnicki, L. (2000). Prawo cywilne w pracach Komisji Kodyfikacyjnej Rzeczypospolitej Polskiej w latach 1919-1939. Wrocław.

16. Gwiazdomorski, J. (1932). Skuteczność orzeczeń sądów duchownych b. Król. Kongr. w sprawach małżeńskich wobec prawa państwowego. Przeglad Prawa i Administracji, R. LVII, nr 1, 4-23.

17. Gwiazdomorski, J., (1935). Trudności kodyfikacji osobowego prawa małżeńskiego w Polsce. Osobne odbicie z “Czasopisma Prawniczego”. Kraków, 174-223.

18. Hahn, Z. (1935). Powaga rzeczy osądzonej. Polski Proces Cywilny, R. III, nr 9, 257-260.

19. Jaglarz, J. (1934). Problem kodyfikacji prawa małżeńskiego w Polsce. Poznań.

20. J. G. (1929). Z praktyki jednego z konsystorzy ewangelickich. Gazeta Sadowa Warszawska, R. LVII, $n r$ 8, 119-120.

21. Jastrzębski, R. (2015). Prawo Prywatne międzydzielnicowe. Zarys problematyki. Krakowskie Studia z Historii Państwa i Prawa, R. VIII, nr 3, 277-298.

22. Krasowski, K. (1995). Prawo o aktach stanu cywilnego w II Rzeczypospolitej. Kwartalnik Prawa Prywatnego, R. IV, z. 2, 227-252.

23. Litwin, J., Rżewski, A. (1931). Rejestracja stanu cywilnego. Warszawa.

24. Mika, K. (2007). Małżeńskie prawo osobowe w projekcie Zygmunta Lisowskiego z 1934 r. [w:] Prawo blisko czlowieka. Z dziejów prawa rodzinnego i spadkowego / red. M. Mikuła. Kraków, 79-85.

25. Osuchowski, J. (1967). Prawo wyznaniowe Rzeczypospolitej Polskiej 1918-1939. Warszawa.

26. Paciorkowski, Sz. (2013). Problem tzw. legalnej bigamii w II RP w świetle spraw małżeńskich toczonych przed Sądem Okręgowym w Poznaniu. Rezpozytorium Uniwersytetu im. Adama Mickiewicza, z. 2, 15-28.

27. Papierzyńska-Turek, M. (1976). Kosciół prawosławny w Polsce w latach 1918-1927 sytuacja prawna i konflikty wewnętrzne. Dzieje Najnowsze, R. VIII, 15-32.

28. Piegzik, A. (2016). Przeszkody małżeńskie w ustawodawstwie dzielnicowym II RP. Folia Iuridica Wratislaviensis, vol. 5(1), 28-36.

29. Prawo malżeńskie (projekt ustawy). (1934) / oprac. Z. Lisowski. Poznań.

30. Prądzyński, E. (1937). Zagadnienie ważności małżeństw cywilnych. Palestra, R. XIV, nr 5, 438-444.

31. Radwański, Z. (1968). Historia Państwa i Prawa Polski 1918-1939 / red. F. Ryszki. Warszawa, $c z$. II.

32. Radwański, Z. (1968). Prawo cywilne i proces cywilny [w:] Historia państwa i prawa Polski 1918-1939 / red. F. Ryszka. Warszawa, cz. II, 169-177.

33. Szymański, T. (1932). Skutki prawne wyroków sądów duchownych. Głos Sądownictwa”, $R$. IV, $n$ r 10, 595-603.

34. Świątkowski, H. (1934). Jeszcze o działalności sądów konsystorskich. Gazeta Sądowa Warszawska", R. LXII, $n r$ 5, 67-69.

35. Świątkowski, H. (1959). Problem legalnej bigamii w Polsce przedwrześniowej. Nowe Prawo, Vol. 15, z. 10, 1150-1158. 
36. Świątkowski, H. (1939). Stan Prawny Polskiego Autokefalicznego Kościoła Prawosławnego (w zarysie). Gtos Sadownictwa, R. XI, nr 7-8, 599-605.

37. Świątkowski, H. (1938). Z praktyki sądów konsystorskich. Gtos Sądownictwa, R. X, nr 2, 107-114.

38. Tylbor, S. (1939). Dzisiejsze prawo małżeńskie w b. Królestwie Kongresowym. Głos Sądownictwa, R. XI, $n r$ 7-8, 581-599.

39. Zbiór Orzeczeń Sadu Najwyższego Retrieved from http://www.sn.pl/orzecznictwo/SitePages/Baza_orzeczen.aspx [dostęp 1.03.2020]

\title{
THE ISSUES OF MATRIMONIAL LAW IN THE EASTERN BORDERLANDS OF THE SECOND POLISH REPUBLIC
}

\section{J. Dworas-Kulik}

\author{
The Johan Paul II Catholic University of Lublin, Collegium Joannis Pauli II, \\ Al. Ractawickie 14, 20 - 950 Lublin, room C-741, \\ e-mail: judytadworas@kul.lublin.pl
}

The presented article describes the issues facing the marriage law in the eastern parts of the Second Polish Republic. In the eastern territories of interwar Poland the regulations of the Russian Imperial Svod favoured the Orthodox faith, so in this area Orthodox Christianity was the most widely cultivated religion. The temporary regulations (essentially assumed to be provisional), intended to regulate the situation of the pro-Russian Orthodox Church, for many years were the only legal basis for Poland's relations with that Church, which as a result gave the Orthodox administrative authorities a great deal of latitude. This resulted in the tendency to isolate the Orthodox Church in Poland as autocephalous, which would not be subordinate to Moscow's authority. Article 114 of the March Constitution indicated that the leading position among the confessions recognized by the state was that of the Roman Catholic denomination. The Orthodox Church justified its position in Article 115 of the March Constitution, and therefore did not respect the superiority of the Catholic Church. Ecclesiastical courts did not respect the judgements passed by courts of other faiths, which resulted in the conflicts between the judgements issued by these courts. They would "snatch" one another's cases falling within the jurisdiction of other courts, a situation which made their judgements legally invalid under civil law. In the Second Polish Republic, against the background of political-religious and legal-religious disputes, a phenomenon emerged which in the contemporary jurisprudence was called legal bigamy. The most frequent example of bigamy was a situation when a husband abandoned his wife and moved to another district where he lived for some time in order to acquire new district rights. Then he changed his religion to the one which entitled him to sue for divorce on more beneficial terms, and afterwards he filed for divorce before an ecclesiastical court. Civil courts were not competent to quash a judgement of an ecclesiastical court issued with exceeding the authority granted by the state, which resulted in a situation where the spouses remained in two parallel marriages. This situation caused confusion in the area of matrimonial property law and inheritance law, and raised doubt as to the legal status of children from the two marriages. Failure to observe state regulations concerning the jurisdiction of ecclesiastical courts in dissolution or nullity cases, as well as mutual non-recognition of judgements of the ecclesiastical courts contributed to the creation of areas called "divorce meccas". These designations referred to the Eastern Orthodox and Calvinist Church existing in the eastern territories of the Second Polish Republic.

Keywords: bigamy, polygamy, marriage, monogamy, Russian Partition, ecclesiastical court. 